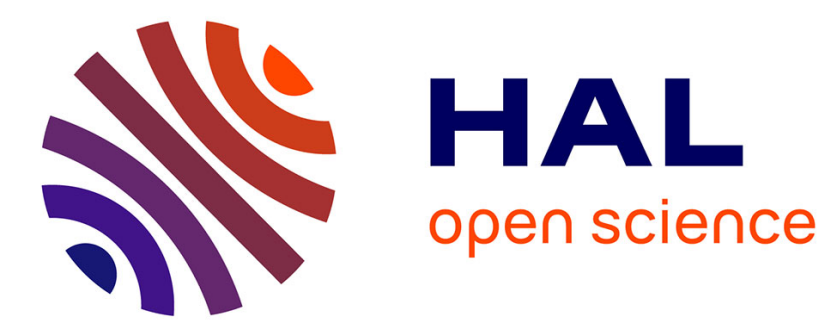

\title{
Targeting DOT1L for mixed-lineage rearranged leukemia
}

\author{
Corentin Bon, Yang Si, Paola B Arimondo
}

\section{To cite this version:}

Corentin Bon, Yang Si, Paola B Arimondo. Targeting DOT1L for mixed-lineage rearranged leukemia. Histone Modifications in Therapy, 20, Elsevier, pp.81-99, 2020, Translational Epigenetics, 978-0-12816422-8. 10.1016/B978-0-12-816422-8.00005-2 . pasteur-03414682

\section{HAL Id: pasteur-03414682 https://hal-pasteur.archives-ouvertes.fr/pasteur-03414682}

Submitted on 24 Nov 2021

HAL is a multi-disciplinary open access archive for the deposit and dissemination of scientific research documents, whether they are published or not. The documents may come from teaching and research institutions in France or abroad, or from public or private research centers.
L'archive ouverte pluridisciplinaire HAL, est destinée au dépôt et à la diffusion de documents scientifiques de niveau recherche, publiés ou non, émanant des établissements d'enseignement et de recherche français ou étrangers, des laboratoires publics ou privés. 


\title{
Chapter 11
}

\section{Targeting DOT1L for mixed-lineage rearranged leukemia}

\author{
Corentin Bon ${ }^{1,2}$, Yang $\mathrm{Si}^{1}$, Paola B. Arimondo ${ }^{1}$
}

${ }^{1}$ Epigenetic Chemical Biology, Department of Structural Biology and Chemistry, Institut Pasteur, UMR3523 CNRS, 75015 Paris, France

${ }^{2}$ Ecole Doctorale MTCI, Université de Paris, Sorbonne Paris Cité, Paris, France

Correspondance: Paola B. Arimondo; EpiCBio Institut Pasteur CNRS UMR3523, email: paola.arimondo@cnrs.fr

\begin{abstract}
Histone methyltransferases are potential therapeutic targets for human diseases, in particular cancer. Among them, DOT1L is a lysine histone methyltransferase (KHMT) that catalyzes the methylation of lysine 79 on histone 3 . Structurally its catalytic domain is distinguished by the presence of seven-stranded $\beta$-sheet motif, common to the arginine histone methyltransferases, making it a unique KHMT. In addition to this unicity, which makes it a very interesting therapeutic target from a medicinal chemistry point of view, DOT1L plays a major role in mixed lineage rearranged leukemia, an important subset of acute leukemia with very poor overall survival rate. Here after an introduction of DOT1L and its role in MLL-r leukemia, we discuss the development of DOTL1 inhibitors for the treatment of MLL-r and the assays used to discover and evaluate the inhibitors.
\end{abstract}

Keywords: histone methylation; inhibitors; MLL leukemia; assay development

\author{
Abbreviations: \\ AlphaLISA= Amplified Luminescent Proximity Homogeneous Assays \\ CETSA = Cellular Thermal Shift Assay \\ DOT1/DOT1L= disruptor of telomeric silencing 1/-like \\ ELISA $=$ enzyme-linked immunosorbent assay \\ $\mathrm{H} 3 \mathrm{~K} 4 \mathrm{me} 1 / 2 / 3=\mathrm{mono} / \mathrm{di} /$ trimethylation of lysine 4 of histone 3 \\ H3K $79 m e 1 / 2 / 3=$ \\ $\mathrm{HCS}=$ High Content Screening \\ HKMT= histone lysine N-methyltransferase \\ $\mathrm{HMT}=$ histone methyltransferase \\ HOXA9= Homeobox A9 \\ HTS $=$ High Throughput Screening \\ ITC $=$ isothermal titration calorimetry \\ MEIS1= Meis Homobox 1
}


MLL= mixed-lineage leukemia

MLL-r= rearranged mixed-lineage leukemia

PRTM $=$ protein arginine $\mathrm{N}$-methyltransferase

RT qPCR $=$ Reverse Transcriptase quantitive PCR

$\mathrm{SAH}=S$-adenosyl-L-homocysteine

$\mathrm{SAM}=S$-adenosyl-L-methionine

$\mathrm{SPA}=$ Scintillation Proximity Assay

$\mathrm{SPR}=$ Surface Plasmon Resonance

\section{Introduction}

\section{DOT1L, a very peculiar histone lysine methyltransferase}

More than 50 human lysine histone methyltransferases (KHMT) have been identified and characterized so far. According to structural and sequence criteria of their catalytic domain, these can be classified into two families: the DOT1-like (DOT1L) and the SET-domain-containing methyltransferases. To date only the DOT1L enzyme belongs to the former family, which is distinguished by the presence of seven-stranded $\beta$-sheet motif, which also structurally characterizes the arginine methyltransferases (PRMTs) family (1).
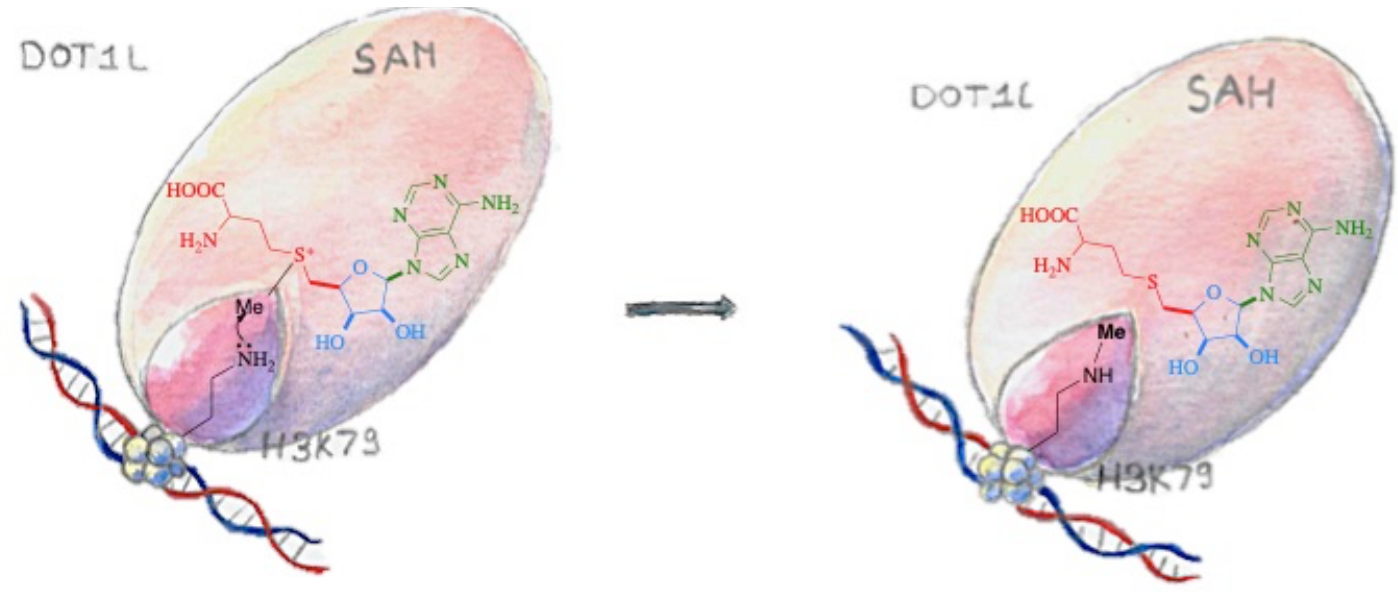

Figure 11.1: Catalytic mechanism of DOT1L. The substrate H3K79 is purple and the SAM. Credit: Justine Prat.

DOT1 (disruptor of telomeric silencing 1) and DOT1L (DOT1-like) catalyze the mono-, di- and trimethylation of histone H3 lysine 79 non-processively (2) using $S$ adenosyl-L-methionine (SAM) as a cofactor (Figure 11.1). These are the only 
methyltransferases of lysine 79 of histone 3 (H3K79) known to date, as demonstrated by observation that the inactivation of these genes in yeast, flies, mice and humans leads to the complete loss of methylation of H3K79 (3). The study of the activity of DOT1L has shown that it acts preferentially on H3K79 in the context of chromatin and is not active on free or recombinant histones H3 (4), suggesting that DOT1L might recognize other nucleosomal features. Unlike most residues in histone $\mathrm{H} 3$ subjected to covalent modifications, which are in the N-terminal tail of the protein, K79 is located in a loop in the globular domain exposed on the surface of the nucleosome (5). This may explain the peculiar structure of this methyltransferase protein. The catalytic activity of DOT1L is based on the first 416 residues of the protein. Mono and di/trimethylation of H3K79 are non-processive process, dependent on SAM (2), which binds to the cofactor binding site closed by an activation loop and a $4 \AA ̊$ methyl transfer channel. This linear channel connects the SAM binding pocket to the substrate binding site, allowing the nucleophilic attack of the deprotonated lysine on the SAM. This structural hypothesis is consistent with the kinetics of an in-line methyl transfer reaction.

Functionally, H3K 79 me $2 / 3$ is an activating mark within the gene body that promotes transcription (6).

\section{Aberrant recruitment of DOT1L in MLL-r leukemia}

The $M L L$ (mixed-lineage leukemia) gene encodes for a large multidomain protein that regulates the transcription of developmental genes, including the HOX genes (7). The amino-terminal portion of the protein contains regions permitting the interaction between the MLL protein and DNA, while the carboxy-terminal portion of the protein exhibits a methyltransferase activity specific for lysine 4 of histone H3 (H3K4). In healthy cells, the MLL protein positively regulates the expression of the HOX genes and is essential for the development of hematopoietic cells. MLL is a specific HMT of H3K4, a mark found in promoters of active loci (8). Rearrangements of the MLL gene in the 11q23 position occur in $5 \%$ to $10 \%$ of acute lymphoid, myeloid or mixed/undetermined leukemia and are particularly common in acute childhood leukemias (70-80\%) and secondary acute myeloid leukemias occurring in patients treated with topoisomerase II inhibitors for other tumors (9). MLL rearrangements result in the loss of the methyltransferase domain at the Cterminal position and a fusion of the $\mathrm{N}$-terminal region with one of the seventy known 
translocation partners (10). The vast majority of translocations result in oncogenic fusion proteins in which the native methyltransferase domain is replaced by sequences derived from AF4 (11), AF9, AF10 and ENL (12), which interact directly or indirectly with DOT1L in complexes inducing di/trimethylation of H3K79 at MLL-targeted genes, such as developmental and pro-leukemic genes, since the gene targeting domain of MLL are conserved in the fusion protein. Consequently, since, contrary to H3K4me2, H3K79me2/3 is an activating mark, this methylation leads to the aberrant expression of a characteristic set of genes including HOXA9 and MEIS1 that lead to leukemogenesis. This was illustrated first by Okada et al showing that MLL-AF10 fusion promotes DOT1L mediated methylation of H3K79 at the HOXA9 promoter (13).

Thus, although DOT1L is not genetically modified as such, the mislocation of its methyltransferase activity and the activation of a leukemic transcriptional gene set are a consequence of the chromosomal translocations observed in MLL patients. DOT1L is therefore involved in the leukemias mediated by MLL fusion partners such as AF4, AF9, AF10 and ENL, which account for two-thirds of all leukemias related to MLL(14). While the precise mechanism by which DOT1L contributes to the gene activation process requires further study, it has been recently shown that DOT1L inhibits the recruitment of a repressive complex composed of SIRT1 and SUV39H1, a methyltransferase of H3K9, on MLL fusion target genes. The final state of chromatin allowing the expression of the gene and therefore the initiation of a leukemic state $(6,15)$ (Figure 2)
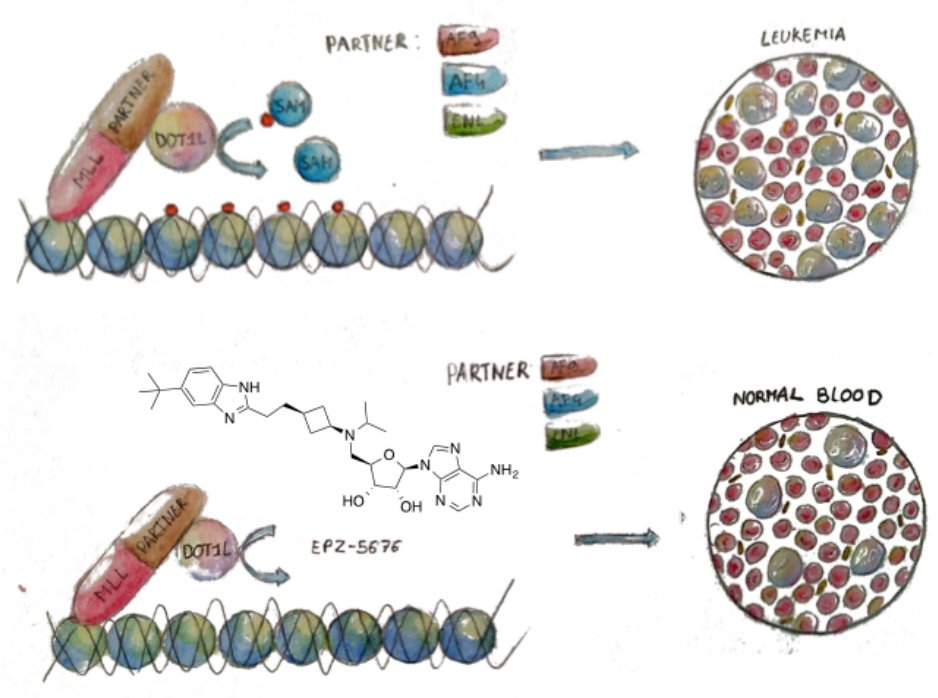
Figure 11.2: Painting the role of DOT1L in leukemia and its targeting as therapeutic strategy. Credit: Justine Prat.

\section{DOT1L as a potential drug target for MLL-r leukemia}

Because its methyltransferase activity is indispensable to the viability of MLL-r cells and seem to be of limited importance for "normal" cells past the development period, inhibition of DOT1L activity or disruption of DOT1L interaction with MLL fusion partners are considered promising therapeutic strategies for the treatment of MLL-r leukemia. Different research groups attempted to developed selective and potent inhibitors of DOT1L but currently only one molecule entered clinical trials for patients with MLL-rearranged leukemia: EPZ-5676 (Figure 11.3).

A first compound, EPZ-4777 (16) was identified by Epizyme as a molecular inhibitor of DOT1L, competing with the SAM cofactor. The chemical structure of this compound retains the nucleoside core of the SAM substrate and the S-Adenosyle-Lhomocysteine $(\mathrm{SAH})$ product. The mechanism was thus supposed to be based on the binding to the SAM pocket, which was confirmed by steady state kinetic analysis (17).

This compound inhibits H3K79 methylation in cancer cells, blocks the expression of leukemogenic genes, and selectively kills cells that contain the translocations on the MLL gene (18). Nevertheless, the compound has poor pharmacological properties (19). A second-generation inhibitor, EPZ-5676 (18), has been tested in Phase I / II clinical trials in the treatment of MLL-rearranged leukemias.

The mechanism of action of the EPZ-4777 compound is very peculiar. EPZ-4777 is a derivative of SAM that inhibits DOT1L with an IC50 of $0.3 \mathrm{nM}$ and possesses surprising selectivity towards DOT1L compared with other SAM-dependent lysine and arginine methyltransferases. 

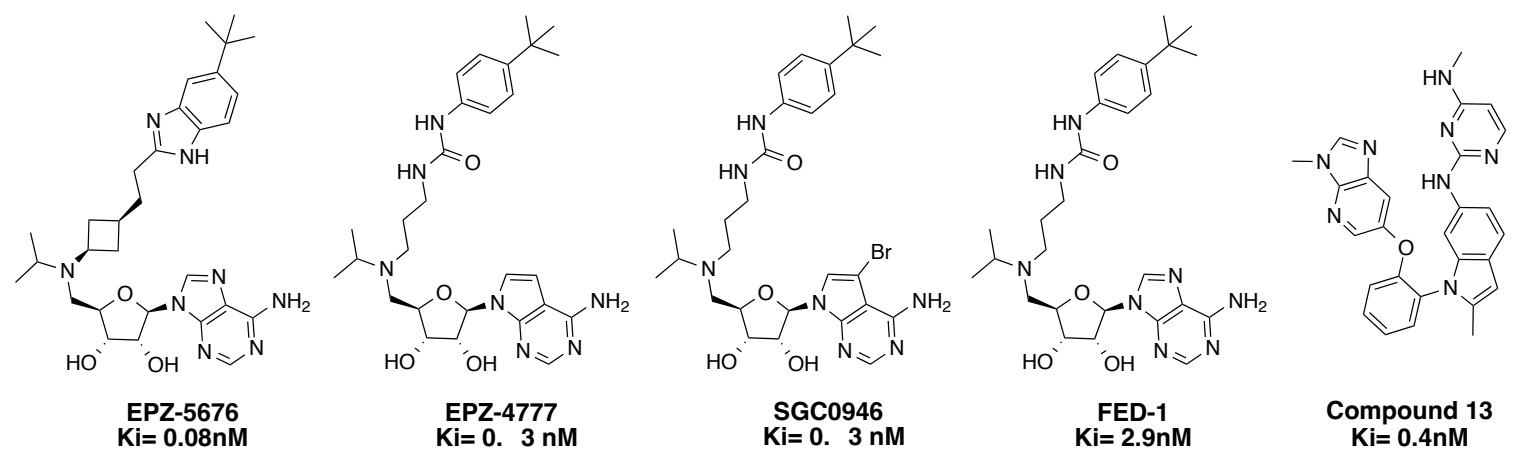

Figure 11.3: Examples of the most potent DOT1L inhibitors.

\section{The chemical inhibitors of DOT1L}

\section{Chemical design of DOT1L inhibitors}

EPZ-4777 was the first lead compound for DOT1L inhibition. The design of the molecule was mechanism-guided (17). In the case of DOT1L, the mechanism is a SN2 reaction, which requires the alignment of the molecular orbital of the methyl donor with the acceptor atoms of the subtract. Modulation of the SAH molecule was started aiming at keeping the recognition pattern of the molecule while reducing the polarity. Consequently, the amino group and the polarizable sulfur (in orange in the Figure 11.4) were removed to obtain a molecule with a minimal amount of pharmacophoric points. The first compound obtained with a reasonable binding affinity was 1 (Figure 11.4). By modification of the 5' amine with low molecular weight substituents and guided by the superposition of the obtain compounds with the SAH crystal structure in DOT1L pocket, 25 compounds were development showing 2 as the most potent. The isopropyl group was assumed to be responsible for the interaction with the lysine binding pocket in DOT1L and thus the moiety was further modulated to improve potency (in red in the Figure 11.4). The next step was to gain interaction with the amino acid pocket while allowing the passage of linker through the methyl channel. After several modification with amino acid-like pharmacophores and several linkers molecule $\mathbf{3}$ with a linker of two carbon and a Fmoc carbamate moiety (in green in the Figure 11.4) was shown to be the most potent. However, this moiety tends to be unstable in vivo, so the interactions of this pharmacophore were studied leading to the conclusion that the $\mathrm{NH}$ interaction and the hydrophobicity of the Fmoc were necessary. It was, thus, replaced with a urea moiety (in blue) bearing a highly hydrophobic phenyl group functionalized in para with a tert-butyl (in purple in Figure 11.4) 
leading to 4 . The linker size was then modulated leading to 5 . Through several modification of the purine moiety (in grey), the deazapurine (in pink in the Figure 11.4) was identified leading to an increase in the potency of $\mathbf{6}$ compared to $\mathbf{5}$. All these features were then regrouped in EPZ-4777. Importantly, the residence time of the molecule in the protein was improved from 5s to $1 \mathrm{~h}$ going from 3 to EPZ-4777 (17).

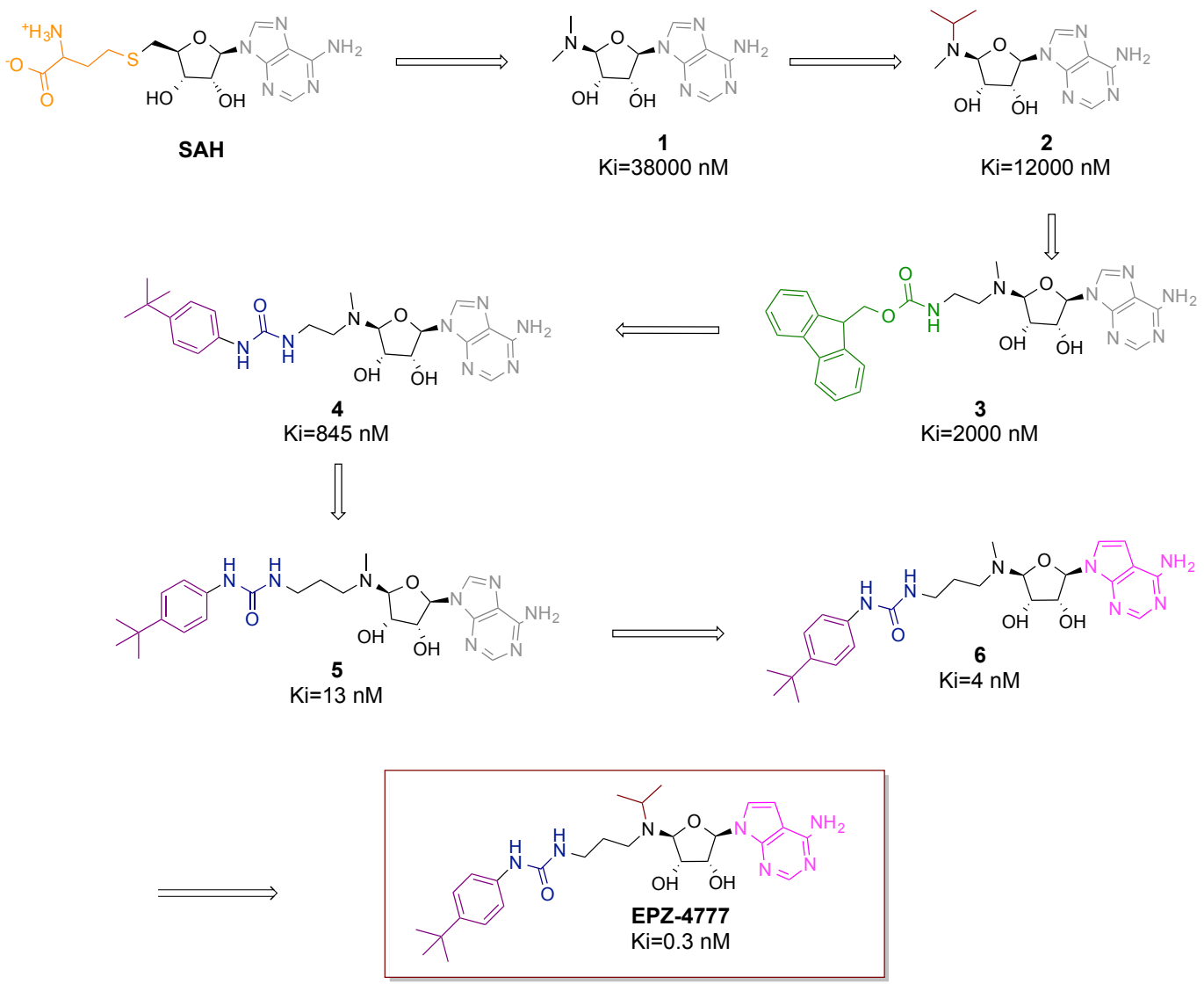

Figure 11.4: Chemical design of EPZ-4777, the first lead compound for DOT1L inhibition

Modification of the urea-containing inhibitor EPZ-4777 $(\mathrm{Ki}=0.3 \mathrm{nM})$ led to the identification of EPZ-5676 possessing an increased potency $(\mathrm{Ki}=0.08 \mathrm{nM})$ and selectivity (over a panel of eight HMTs) (18). The propane linker and the 4-tert-butylphenyl substituted urea moiety of EPZ-4777 (in blue and purple in Figure 11.5) were replaced by 
a cis-ethylcyclobutane linker and a 5-tert-butylbenzimidazole ring (in green and blue, respectively) in order to reduce conformational flexibility and hydrogen bond donors and diminish the entropy to increase the binding.
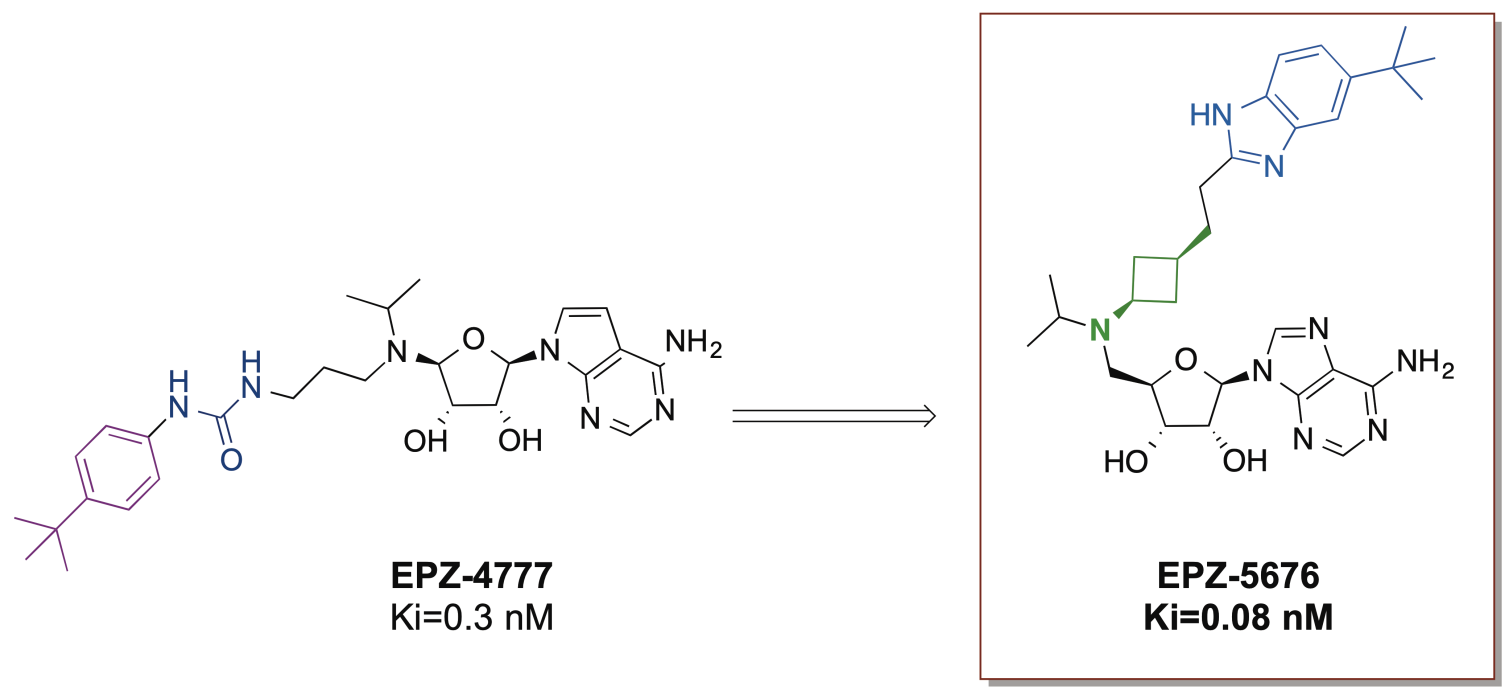

Figure 11.5: Modulation of EPZ-4777 to lead to the clinical compound EPZ-5676.

Structural modelling studies of EPZ-4777 bound to the SAM-binding pocket of DOT1L failed to identify a ligand conformation that could accommodate this bulky substituent within the amino-acid-binding pocket (19).

\section{Mechanism of inhibition}

In order to solve the binding mode of the compound in DOT1L, the crystal structure of EPZ-4777 bound to the DOT1L protein was obtain by soaking in the SAH-DOT1L complex. This led to the determination of the structure of EPZ-4777 in DOT1L with a 2.4A resolution (19).The overall structure is almost superimposable to the one of DOT1L bound to SAM with the exception of the activation and substrate-binding loops that are disordered in the EPZ-4777-bound structure. As expected, EPZ-4777 occupies the cofactor-binding site, while the tert-butylphenyl moiety of the drug cannot fit in the SAMbound conformation of the cofactor pocket. Large structural rearrangements at Tyr312 and Thr139, in the substrate-binding and activation loops, respectively, are necessary to accommodate this portion of the inhibitor. These two residues have been shown to be an 
important feature of the methyl transfer canal. Indeed, mutation of the tyrosine to alanine at this position leads to loss of DOT1L activity. In the presence of the EPZ-4777, it is rotated away from the channel to accommodate the tert-butyl moiety increasing the inhibition activity. At the same time, Thr139 moves by almost $6 \AA$ from the SAM binding site. These conformational changes disrupt the structural integrity of the catalytic pocket and lead to the disruption of the activation and substrate-binding loops. The elucidation of the mechanism of action thus indicates the creation of a hydrophobic pocket in the enzyme were the catalytic activity should take place. These conformational changes render DOT1L non-functional. These modifications can also explain the important residency time of the compound in the pocket.

The binding mode of EPZ-5676 is the same and the diminution of entropy obtained by the more rigid skeleton leads to an increased residence time going from $1 \mathrm{~h}$ for EPZ4777 to 24 h for EPZ-5676.

\section{Perspective for DOT1L inhibitors development}

Other compounds have been developped in recent years, such as SGC0946, a brominated analogue of EPZ-4777. This modification greatly increased cellular inhibitory potency of SGC0946 because of the improved cell permeability(19). However, SGC0946 specifically kills MLL translocated with AF9 but not cells transformed with another leukemogenic fusion protein (20). FED1 is an analog of EPZ-4777 less active but very attractive because of the easy synthetic procedure. Additionally, FED1 has a modestly reduced binding potency for DOT1L that make it easier to use for competition binding assay development across a broad range of inhibitors. A non nucleoside compound, compound 13 (Figure 11.3), has been developed by Novartis through a medicinal chemistry campaign, strongly guided by structure-based considerations that lead to a new class of compounds with a specific binding mode outside of the SAM pocket. Compound 13 presents good pharmacodynamic properties and an $\mathrm{IC}_{50}$ of $340 \mathrm{nM}$ against MOLM13 proliferation and 128nM against MV4-11 proliferation, making it a very potent compound in cells. Moreover, this class of compound was shown to be orally available (33).

In silico methods have also been developed and validated experimentally in order to visit a larger chemical landscape and thus find new compounds with potent activity against 
DOT1L (21). To develop new inhibitors, methods to screen and determine the biological activity are needed. The most common techniques are discussed.

\section{The biological assays to screen for new DOT1L inhibitors.}

Nowadays, multiple techniques area available to evaluate the activities of small molecules as inhibitors of DOT1L. Most widely-used are in vitro biochemical assays that are robust and sensitive. However, a disadvantage of most biochemical and biophysical assays is that they cannot provide actual interactions occurring in living cells. Thus, cellbased assays are developed in parallel to provide information of inhibitors' cell permeability, toxicity and effect on epigenetic marks in native cellular state (22).

Here, we highlight commonly used biological assays to evaluate the potency of DOT1L methyltransferase inhibitors. We provide examples of their utilization; assess their advantages as well as drawbacks. Although we focus on DOT1L, most of these assays can be applied to evaluate small molecule activities against other HMTs.

\section{Radioactivity-based assay}

Standard radioactivity assay in vitro has been considered as the gold standard for monitoring methyltransferase activity (23). It is sensitive and straight-forward. Briefly, the tritiated methyl groups from ${ }^{3} \mathrm{H}-\mathrm{SAM}$ are firstly enzymatically transferred to the protein substrates of HMTs. In a second step, the methylated substrates are separated from the unreacted SAM for scintillation counting or SDS-PAGE gel for autoradiography (24).This standard in vitro approach is sensitive and can be applied to most HMTs, however, it is time-consuming, which strongly impedes the high-throughput screening (HTS) to screen multiple chemical libraries (25).

\section{Filter-binding Assay}

Radioactive filter-binding assay has a higher throughput (26). Since cation exchange filters (phosphor-cellulose paper or anion glass fiber filter) can bind peptides or proteins with higher affinity than free SAM, , after the in vitro methylation reaction, the reaction mixture is transferred on individual filter paper or filter assembled 96- or 384-well plate. The unreacted ${ }^{3} \mathrm{H}-\mathrm{SAM}$ can be filtered off with buffer, while the methylated protein/peptides products remain on the filters and then are quantified by scintillation counting (25). This technique has been extensively used to identify and characterize 
inhibitors targeting DOT1L (16, 17, 19, 27-29). For example, by using filter-binding assay, after the identification of SGC0946 (Figure 311.), Yu et al. compared SGC0946 with other five DOT1L inhibitors including EPZ-4777 $\left(\mathrm{IC}_{50}=0.5 \pm 0.1 \mathrm{nM}\right)$ and FED1 $\left(\mathrm{IC}_{50}=2.9 \pm 0.2 \mathrm{nM}\right)$, showing that SGC0946 has an $\mathrm{IC}_{50}$ of $0.3 \pm 0.1 \mathrm{nM}(19)$.

The obvious advantages of this approach are high sensitivity and easy implantation. However, the drawbacks of this assay are to work with radioactive agents, with several washing steps, the process is not suitable for automation, restricting its application in HTS.

\section{Scintillation proximity assay (SPA)}

In order to remove the washing step in filter-binding assay as well as to improve the throughput, Jeltsch's group developed the scintillation proximity assay (SPA) for HMTs activity assessments and inhibitors screening that was largely used for HMTs (30-32). Biotinylated histone peptides or protein substrates are firstly immobilized on streptavidincoated microscopic capsid beads within the scintillation fluid. Afterwards, the HMT and ${ }^{3} \mathrm{H}$-SAM are added, following the methylation reaction the ${ }^{3} \mathrm{H}$-labeled peptide is immobilized on the streptavidin beads creating the proximity between the ${ }^{3} \mathrm{H} \beta$-emitter and the scintillation fluid, thus resulting in a scintillation signal. One main advantage is that there is no washing step required to remove the unreacted ${ }^{3} \mathrm{H}-\mathrm{SAM}$ since the $\beta$-emission from the unreacted ${ }^{3} \mathrm{H}-\mathrm{SAM}$ is relatively far from the scintillation beads and thus quenched by the solvent (30-32).

The SPA has also been used to study DOT1L kinetics and characterize lead compounds (19, 29-33). For example, Daigle et al. identified EPZ-4777 with an $\mathrm{IC}_{50}$ of $0.4 \pm 0.1 \mathrm{nM}$ (Figure 11.3). A panel of human HMT enzymes were tested in the same conditions, displaying a remarkable selectivity of EPZ-4777 for DOT1L over other HMTs (16). Chen et al. displayed a structure-based fragmentation approach to discover novel inhibitors of DOT1L and used SPA to measure the $\mathrm{IC}_{50}$ of thirteen compounds leading to the potent, selective compound $\mathbf{1 3}$ (Figure 11.3) with an $\mathrm{IC}_{50}$ of $0.4 \mathrm{nM}$ (33).

Besides the drawbacks such as radioactive wastes disposal, time-consuming, the radioactive assays provide a highly sensitive, robust and accurate approach to determine the enzymatic activities of HMT, and to measure the potency of potential DOT1L inhibitors. 


\section{Antibody-based assays}

In addition to biochemical assays, it is important to evaluate the biological activity of the inhibitors in cells. The first option is to analyze the impact of the inhibitor on the methylation catalyzed by DOT1L: the di/trimethylation of lysine 79 on histone 3 (H3K79me2/3). Traditional antibody-based assay including Western blot (16, 18, 19, 34, 35 ) or enzyme-linked immunosorbent assay (ELISA) $(17,18,33)$ are commonly used for the analysis of global cellular levels of H3K79me2 modifications upon compounds treatment. Generally the demethylation is analysed because the antibodies are more specific than the since antibodies against H3K79me3 that usually cross-react to di-methyl K79 (36).The general process involves inhibitor treatment of cells or protein substrates followed by Western blot or ELISA analysis using histone methylation-specific antibodies.

Western blot and ELISA are widely-used assays that can be easily implanted in the lab. However, they both suffer from drawbacks such as time consuming, low-throughput, dependence on antibody quality and sensitivity, and are semi-quantitative. The ELISA assay has multiple washing steps that limit the automation manipulation (25). For Western blot, after compounds treatment, a cell lysis procedure is required ideally followed by nuclear extraction. This is time consuming and affects the throughput level as well as impact on the sensitivity and accuracy (22).

For HTS, Amplified Luminescent Proximity Homogeneous Assays (AlphaLISA) is of choice. It is a bead-based, highly sensitive, no-wash antibody-based assay developed by PerkinElmer for the detection of global histone methylated levels by using a luminescent oxygen-channeling chemistry $(37,38)$. AlphaLISA DOT1L assay detects the dimethylation of H3K79 using an anti-histone $\mathrm{H} 3$ acceptor beads and a biotinylated H3K79me2 antibody. It consists of two steps, the enzymatic reaction step and the alpha signal detection step. Firstly, recombinant DOT1L protein, SAM and oligonucleosomes substrates are mixed with compounds in a 384-well microplate format. After stopping the enzymatic reaction by the addition of high salt buffer, the anti-histone $\mathrm{H} 3$ acceptor beads and biotinylated antiH3K79me2 antibody are added for incubation then followed by addition of the streptavidin donor beads. Thus, the biotinylated antibody is captured by streptavidin donor beads and, upon laser irradiation, these two beads in proximity generate an amplified chemiluminescent signal, proportional to the methylation activity of the recombinant 


\section{DOT1L.}

AlphaLISA provides a fast and high sensitivity assay. Due to its no washing step, small sample quantity and homogeneous signal, it is suitable for HTS screening $(27,28)$. However, it's use is limited by the price. Song et al. applied AlphaLISA assay to the HTS screening against DOT1L of a chemical library of about 20000 molecules. Five small compounds with DOT1L inhibitory activities were identified for further optimization (28) Yi et al. used AlphaLISA DOT1L assay to evaluate the potency of several inhibitors, an $\mathrm{IC}_{50}$ of $5.3 \mathrm{nM}$ and $22.4 \mathrm{nM}$ are determined for EPZ-4777 and FED1 (Figure 11.3), respectively (34).

\section{Affinity-based Assay}

To evaluate the binding affinity of the compounds to DOT1L, several biophysical strategies have been developed on the purified proteins and in cells. These techniques provide several biophysical parameters that characterize the interactions of the compounds with DOTL1.

\section{Surface Plasmon Resonance (SPR)}

The conventional affinity binding technique such as Surface Plasmon Resonance (SPR) is widely-used to assess the interaction between compounds and DOT1L $(17,19,27,28$, 33). In a typical experiment, DOT1L proteins are immobilized on chip followed by a flow of the compounds in series concentration, the equilibrium dissociation constant $K_{D}$ is calculated to evaluate the affinity of the compounds. Yu et al. used SPR to compare SGC0946 with other five DOT1L inhibitors including EPZ-4777 $\left(\mathrm{K}_{\mathrm{D}}=0.25 \pm 0.02 \mathrm{nM}\right)$, showing that SGC0946 has a $\mathrm{K}_{\mathrm{D}}$ of $0.06 \pm 0.01 \mathrm{nM}$ in agreement with the biochemical analysis. They also demonstrated that SGC0946 and EPZ-4777 bind to DOT1L with a 1:1 stoichiometry (19).

\section{Isothermal titration calorimetry (ITC)}

Another biophysical assay to quantitatively measure the direct binding affinity of the potential inhibitors to DOT1L is isothermal titration calorimetry (ITC). The enthalpy of binding of DOT1L and compounds are measured by calorimeter. By fitting the binding isotherms, the $K_{D}$ was calculated to confirm the binding affinities of the inhibitors $(19,34$, 
35). Yu et al. confirmed that the complex of DOT1L and EPZ-4777 has a binding stoichiometry of 1:1 as by SPR (19).

The obvious advantage of SPR and ITC is their selectivity and sensitivity. However, they cannot provide the real interactions between inhibitors and proteins occurring inside the nucleus of living cells. Thus, follow-up studies such as cellular thermal shift assay (CETSA) are needed for evaluate compounds affinity in live cells.

\section{Cellular thermal shift assay (CETSA)}

Cellular thermal shift assay (CETSA) is used to further measure the biophysical interaction of the potential inhibitors with DOT1L in live cells. After treating cells with inhibitors, cells were washed, spited and heated at a series of temperature points. Cells were then lysed and analyzed by Western blot to quantify the DOT1L intensity, since unbound proteins denature and precipitate at raising temperatures while the inhibitor bound complexes remain in solution (22). Zhu et al. used CETSA to show that the chemical probes P1 and P2 of the inhibitor FED1 bind with endogenous DOT1L in A431 cells, and behave similarly compared to the parent compound FED1 (35).

Besides drawbacks such as cell lysis steps, time-consuming assay and antibody specificity, CETSA provides a homogeneous approach to determine direct binding affinity of the compounds to DOT1L in live cells.

\section{Cell-based assay}

As we have discussed previously, for most biochemical assays such as radioactivity assay and AlphaLISA, the disadvantage is that they required purified recombinant enzymes (i.e., DOT1L recombinant proteins) and histone substrates (i.e., natural oligonucleosomes substrates), which cannot provide the real interactions occurring inside the nucleus of living cells. A potent inhibitor identified in a biochemical assay is not guaranteed to be active in cells. Cell-based assay are thus required providing the information of inhibitors' cell permeability and toxicity together with on target activity and engagement (22).

\section{Cell proliferation inhibition assay}

Compounds are added to cells and phenotypes of interest are measures (e.g., cell death, proliferation, permeability, etc.)

Cell lines MOLM-13 and MV4-11 are widely used in cell proliferation inhibition assays for evaluate inhibitor activities against DOT1L (16-18, 27, 28, 33). For example, 7 days 
treatment of MV4-11 and MOLM-13 cells with $3 \mu \mathrm{M}$ EPZ-4777 decreased the number of viable cells, the $\mathrm{IC}_{50}$ being $0.17 \mu \mathrm{M}$ for MV4-11 and $0.72 \mu \mathrm{M}$ for MOLM-13(16). The nonMLL-rearranged cell line (Jurkat cells) was used as a control showing the specificity of the drug for MLL-r cells. EPZ-5676 is more potent than EPZ-4777 with an $\mathrm{IC}_{50}=3.5 \mathrm{nM}$ for MV4-11 and $\mathrm{IC}_{50}=28 \mathrm{nM}$ for MOLM-13 (18).

Cell proliferation inhibition assay has the advantage to provide drug activity information on disease-related cells directly on long time scale (up to 60 days)(39). Moreover, cell cycle and apoptosis by flow cytometry are usually implanted to evaluate the compounds the effects on cell differentiation and apoptosis in MLL-Rearranged cells

However, it does not give indications on off-target effects and selectivity of the compounds. Therefore, other assays are needed to investigate the specificity of action on H3K79me2/3 compared to other targets in parallel.

\section{Quantitative Reverse Transcriptase PCR}

In addition to the effect on $\mathrm{H} 3 \mathrm{~K} 79 \mathrm{me} 2 / 3$, it is important to follow the changes in gene expression upon treatment of rearranged leukemia cells with the compounds, in particular on specific target gense. As discussed above, in MLL-rearranged leukemias, HOXA9 and MEIS1 are commonly overexpressed by the aberrant $\mathrm{H} 3 \mathrm{~K} 79 \mathrm{me} 2 / 3$ due to the recruitment of DOT1L by MLL-fusion proteins.

Quantitative RT PCR is the method of choice to quantify the impact of the drug treatment on HOXA9 and MEIS1 transcript levels in MLL fusion-expressing cells (16-19, 34). Commonly used acute leukemia cell lines harboring MLL fusions are MOLM-13(MLLAF9) and MV4-11(MLL-AF4).

For example, compound EPZ-4777 depletes HOXA9 and MEIS1 transcript levels in MOLM-13 and MV4-11 cells after 6-8 days of treatment (16).

Although, quantitative real-time PCR measure transcript levels are highly sensitive and highly specific, the technique is time-consuming and induces variability that can be overcome by doing several biological replicates.

\section{Fluorescence-based Assay}

Immunofluorescence imaging has been used to follow the impact of the compounds on selective histone marks, using methylation specific antibodies detected by fluorescence 
microscope directly in cells. For example, it was assed the impact of DOT1L inhibitors on the dimethylated states of H3K79. Zhu et al. incubated inhibitor FED1 (Figure 3), probes $\mathrm{P} 1$ and $\mathrm{P} 2$ with A431 cells at $5 \mu \mathrm{M}$ for 4 days. The cells were fixed and labelled with antiH3K79me2 antibody followed by a dye-labeled secondary antibody. The cells treated with drugs dramatically decreased the fluorescence signal compared to DMSO-treated cells. These results are consistent with Western blot assay (35). This cellular approach enables a direct readout of the compound activity in cells. However, it depends on the selectivity of the antibodies that can be limiting.

\section{High Content Screening (HCS)}

High Content Screening (HCS) is an advanced approach of cell-based screening in drug discovery, which combines automated recording of multi-color fluorescence imaging and high-throughput quantitative data analysis (40). The developments of automated HCS allow to screen and evaluate the compounds activity on multiple epigenetic marks directly.

In a typical DOT1L HCS screening assay, cells are seeded in 96 or 384 well-plate with different drugs treatment. After the treatment, cells are fixed and H3K79me2 histone mark inside the cell is labelled with antibodies compatible for immunofluorescence. In HCS, multiple images are processed for quantitative analysis to evaluate the compound activity on H3K79 mark $(19,34)$.

By HCS, Yi et al. evaluated the DOT1L inhibitors EPZ-4777 and FED1 inhibition potency on $\mathrm{H} 2 \mathrm{~K} 79 \mathrm{me} 2$ in A431 cells upon 4 days of treatment in a series diluted concentration. After immunofixation, the samples were screened by HCS and the $\mathrm{IC}_{50}$ for EPZ-4777 is found around $0.05 \mu \mathrm{M}$ and for FED1 is around $0.1 \mu \mathrm{M}$ (34) in agreement with Western blot analysis.

The main advantage of HCS is that it can be applied to screen large chemical libraries and it allows quantitative information as a first-level description of complex cellular histone methylation events based on "big data". The major drawback is the antibody specificity and this needs to be considered during assay developments $(22,36)$.

\section{Conclusions and Perspectives}


We have described the chemical design of the most potent inhibitors. Further research efforts are ongoing. The diversity of the chemical libraries needs to be increased and screened. In silico approaches are also implemented. An option is to target the proteinprotein interactions between DOT1L and the translocated partners, for example with small molecules or stapled peptides as has been done for other methyltransferases(41).Fragmentbased screening screening approaches are also very promising. Scheufler et al. optimized, guided by X-rays cocrystal structures, a weak fragment-based screening hit by SPR to obtain compound 8 with an $\mathrm{IC}_{50}$ of 14nM against DOT1L (measured by SPA)(42), opening a new vector for fragment growing. In a following study, the continued the fragment-based approach guided by X-rays cocrystal structures working on the adenosine replacement to obtain compound 7 with an $\mathrm{Ki}$ of $0.002 \mathrm{nM}$ against DOT1L (measured by SPA), comparable to EPZ-5676 or more active in vitro (Ki $0.012 \mathrm{nM})$ and in cells(43).

In parallel, we have highlighted and discussed the most common approaches that have been used to evaluate the activities of small molecule against DOT1L. Table 11.1 shows the comparison of three techniques on the purified enzyme that evaluate the inhibitory potency.

\begin{tabular}{|c|c|c|c|c|c|}
\hline Assays & Target & Unit (nM) & EPZ-4777 & SGC0946 & FED1 \\
\hline SPR & DOT1L & $\mathrm{K}_{\mathrm{D}}$ & $0.25 \pm 0.02(19)$ & $0.06 \pm 0.01(19)$ & $1.99 \pm 0.15(19)$ \\
\hline $\begin{array}{l}\text { Radioactivity } \\
\text {-based }\end{array}$ & DOT1L & Inh. $\mathrm{IC}_{50}$ & $\begin{array}{ll}0.3 \pm 0.02 & (18) \\
0.4 \pm 0.1 & (16) \\
0.5 \pm 0.1 & (19)\end{array}$ & $0.3 \pm 0.1 \quad(19)$ & $2.9 \pm 0.2 \quad(19)$ \\
\hline AlphaLISA & DOT1L & Inh. $\mathrm{IC}_{50}$ & $(34)$ & ND & 22.4 \\
\hline \multicolumn{6}{|c|}{$\mathrm{K}_{\mathrm{D}}$ is the equilibrium dissociation constant of compound against DOT1L. } \\
\hline \multicolumn{6}{|c|}{$\mathrm{IC}_{50}$ is the concentration of compound that results in a half-maximal degree of inhibition. } \\
\hline
\end{tabular}

In Table 11.2 summarizes the applications, advantages /disadvantages of all techniques. 
As a gold standard assay for characterization of HMTs activity, radioactive assays including filter-binding assay and scintillation proximity assay are widely-used in validation of new small molecule as inhibitors of DOT1L. Their limitation is the throughput capacity. AlphaLISA DOT1L assay, on the other hand, provides a fast, high sensitivity assay compatible with high automatization, but is expensive. Antibody-based assays such as Western blot or ELISA are most commonly used to detect the global cellular levels of H3K79me2 modifications upon compounds treatment of cells. However, they have drawbacks such as time consuming, low-throughput, semi-quantitative. Affinitybased assays such as SPR and ITC provide binding affinity in vitro while the CETSA provides interaction information in vivo. Quantitative real-time PCR is used to evaluate the potency of small molecule inhibitors on transcript levels in MLL fusion-expressing cells with high sensitivity and high specificity. Cell proliferation inhibition assay, which is important to conduct in follow-up studies, provide information of inhibitors' cell permeability and toxicity as well as potency and selectivity. The developments of automated HCS allow the screen of large chemical libraries on multiple epigenetic marks simultaneously. 


\begin{tabular}{|c|c|c|c|c|c|c|}
\hline Assays & Method & Throughput & Applications & Advantages & Limitations & References \\
\hline \multirow[t]{2}{*}{$\begin{array}{l}\text { Radioactivity- } \\
\text { based }\end{array}$} & $\begin{array}{l}\text { Filter- } \\
\text { binding } \\
\text { Assay }\end{array}$ & Low & $\begin{array}{l}\text { Inhibition } \\
\text { potency of the } \\
\text { catalytic activity } \\
\text { in vitro }\end{array}$ & $\begin{array}{l}\text { High sensitivity; } \\
\text { Gold standard; Straight-forward }\end{array}$ & $\begin{array}{l}\text { Radioactive wastes; } \\
\text { Time-consuming }\end{array}$ & $(19,27-29)$ \\
\hline & $\begin{array}{l}\text { Scintillation } \\
\text { Proximity } \\
\text { Assay (SPA) }\end{array}$ & High & $\begin{array}{l}\text { Inhibition } \\
\text { potency of the } \\
\text { catalytic activity } \\
\text { in vitro }\end{array}$ & $\begin{array}{l}\text { High sensitivity; } \\
\text { Small quantity; } \\
\text { HTS-compatible }\end{array}$ & Radioactive wastes & $(16,17,29,33)$ \\
\hline \multirow[t]{3}{*}{$\begin{array}{l}\text { Antibody- } \\
\text { based }\end{array}$} & Western Blot & Low & $\begin{array}{l}\text { Activity in cells } \\
\text { on H3K } 79 \\
\text { methylation }\end{array}$ & Easy implantation & $\begin{array}{l}\text { Moderate sensitivity; } \\
\text { Antibody specificity; } \\
\text { Semi-quantitative; } \\
\text { Time-consuming }\end{array}$ & $(16,18,19,34,35)$ \\
\hline & ELISA & Medium & Effects in cells & $\begin{array}{l}\text { Direct readout; } \\
\text { Easy implantation }\end{array}$ & $\begin{array}{l}\text { Moderate sensitivity; } \\
\text { Antibody specificity; } \\
\text { Semi-quantitative; Non- } \\
\text { homogeneous }\end{array}$ & $(17,18,33)$ \\
\hline & AlphaLISA & High & $\begin{array}{l}\text { Inhibition } \\
\text { potency of the } \\
\text { catalytic activity } \\
\text { in vitro } \\
\text { HTS }\end{array}$ & $\begin{array}{l}\text { High sensitivity; Rapid; } \\
\text { Homogeneous; } \\
\text { Small sample quantity; } \\
\text { No washing steps }\end{array}$ & $\begin{array}{l}\text { Antibody specificity; } \\
\text { High costs }\end{array}$ & $(27,28,34)$ \\
\hline \multirow[t]{3}{*}{$\begin{array}{l}\text { Affinity- } \\
\text { based }\end{array}$} & SPR & Medium & $\begin{array}{l}\text { Binding affinity } \\
\text { and selectivity }\end{array}$ & $\begin{array}{l}\text { High sensitivity; } \\
\text { High selectivity }\end{array}$ & $\begin{array}{l}\text { Time-consuming; } \\
\text { High costs }\end{array}$ & $(17,19,27,28,33$ \\
\hline & ITC & Medium & $\begin{array}{l}\text { Binding affinity } \\
\text { and selectivity }\end{array}$ & $\begin{array}{l}\text { High sensitivity; } \\
\text { High selectivity }\end{array}$ & $\begin{array}{l}\text { High quantity of materials } \\
\text { needed }\end{array}$ & $(19,34,35)$ \\
\hline & CETSA & Low & $\begin{array}{l}\text { In cells binding } \\
\text { affinity and } \\
\text { selectivity }\end{array}$ & $\begin{array}{l}\text { Homogeneous; } \\
\text { Easy implantation }\end{array}$ & $\begin{array}{l}\text { Moderate sensitivity; } \\
\text { Antibody specificity; } \\
\text { Semi-quantitative; } \\
\text { Time-consuming }\end{array}$ & (35) \\
\hline \multirow[t]{2}{*}{ Cell-based } & $\begin{array}{l}\text { Cell } \\
\text { proliferation } \\
\text { inhibition } \\
\text { assay }\end{array}$ & Medium/High & $\begin{array}{l}\text { Potency in cells, } \\
\text { selectivity, } \\
\text { permeability and } \\
\text { toxicity }\end{array}$ & Disease-related readout & $\begin{array}{l}\text { Indirect influences from off- } \\
\text { targets and the cellular } \\
\text { environment }\end{array}$ & $(16-18,27,28,33)$ \\
\hline & $\begin{array}{l}\text { Quantitative } \\
\text { real-time } \\
\text { PCR }\end{array}$ & Medium/High & $\begin{array}{l}\text { Effects on gene } \\
\text { expression in } \\
\text { cells }\end{array}$ & $\begin{array}{l}\text { High sensitivity; } \\
\text { High specificity }\end{array}$ & $\begin{array}{l}\text { Knowledge of target gene } \\
\text { required; } \\
\text { Time-consuming }\end{array}$ & $(16-19,34)$ \\
\hline $\begin{array}{l}\text { Fluorescence- } \\
\text { based }\end{array}$ & $\begin{array}{l}\text { High Content } \\
\text { Screening } \\
\text { (HCS) }\end{array}$ & High & $\begin{array}{l}\text { Effects in cells } \\
\text { HTS }\end{array}$ & $\begin{array}{l}\text { Automated recording; } \\
\text { Multiple histone marks } \\
\text { simultaneously; } \\
\text { First-level description of complex } \\
\text { cellular histone methylation } \\
\text { events }\end{array}$ & Antibody specificity & $(19,34)$ \\
\hline
\end{tabular}


These biological assays are complementary and results are combined to have a broader overview of the compound activity. Most of the assays are well-established and easily implanted. However, development and optimization of novel biological assays are still necessary in help to rapid and accurate identification of selective DOT1L inhibitors with therapeutic potential.

Interestingly, new roles of DOT1L are being highlighted in diseases, confirming its potential as target. For example, in addition to leukemia, DOT1L has been reported to play a role in prostate cancer. It was reported to directly methylate the androgen receptor, leading to enhanced androgen-receptor-mediated transcriptional activation and proliferation in prostate cancer cells (44). Moreover, H3K79me2 increase progressively with aging suggesting its role in aging process (45): DOT1L seems like an attractive target for diseases associated with aging disregulation such as Hutchinson-Gilford progeria syndrome(46). Therefore, there is a need to identify and develop novel inhibitors with scaffolds that show higher diversity and are more stable pharmacologically.

\section{Acknowledgement}

The authors thank Justine Prat for her participation for the realization of the figures.

\section{References}

1. Min J, Feng Q, Li Z, Zhang Y, Xu RM. Structure of the catalytic domain of human DOT1L, a non-SET domain nucleosomal histone methyltransferase. Cell. 2003;112(5):711-23.

2. Frederiks F, Tzouros M, Oudgenoeg G, van Welsem T, Fornerod M, Krijgsveld J, et al. Nonprocessive methylation by Dot1 leads to functional redundancy of histone H3K79 methylation states. Nat Struct Mol Biol. 2008;15(6):550-7.

3. Jones B, Su H, Bhat A, Lei H, Bajko J, Hevi S, et al. The histone H3K79 methyltransferase Dot1L is essential for mammalian development and heterochromatin structure. PLoS Genet. 2008;4(9):e1000190.

4. Feng Q, Wang H, Ng HH, Erdjument-Bromage H, Tempst P, Struhl K, et al. Methylation of H3-lysine 79 is mediated by a new family of HMTases without a SET domain. Curr Biol. 2002;12(12):1052-8.

5. Luger K, Mader AW, Richmond RK, Sargent DF, Richmond TJ. Crystal structure of the nucleosome core particle at 2.8 A resolution. Nature. 1997;389(6648):251-60.

6. Wood K, Tellier M, Murphy S. DOT1L and H3K79 Methylation in Transcription and Genomic Stability. Biomolecules. 2018;8(1). 
7. Hess JL. MLL: a histone methyltransferase disrupted in leukemia. Trends Mol Med. 2004;10(10):500-7.

8. Barski A, Cuddapah S, Cui K, Roh TY, Schones DE, Wang Z, et al. High-resolution profiling of histone methylations in the human genome. Cell. 2007;129(4):823-37.

9. Tamai H, Inokuchi K. 11q23/MLL acute leukemia : update of clinical aspects. J Clin Exp Hematop. 2010;50(2):91-8.

10. Krivtsov AV, Armstrong SA. MLL translocations, histone modifications and leukaemia stem-cell development. Nat Rev Cancer. 2007;7(11):823-33.

11. Bitoun E, Oliver PL, Davies KE. The mixed-lineage leukemia fusion partner AF4 stimulates RNA polymerase II transcriptional elongation and mediates coordinated chromatin remodeling. Hum Mol Genet. 2007;16(1):92-106.

12. Mueller D, Bach C, Zeisig D, Garcia-Cuellar MP, Monroe S, Sreekumar A, et al. A role for the MLL fusion partner ENL in transcriptional elongation and chromatin modification. Blood. 2007;110(13):4445-54.

13. Okada Y, Feng Q, Lin Y, Jiang Q, Li Y, Coffield VM, et al. hDOT1L links histone methylation to leukemogenesis. Cell. 2005;121(2):167-78.

14. Ayton PM, Cleary ML. Molecular mechanisms of leukemogenesis mediated by MLL fusion proteins. Oncogene. 2001;20(40):5695-707.

15. Chen CW, Koche RP, Sinha AU, Deshpande AJ, Zhu N, Eng R, et al. DOT1L inhibits SIRT1-mediated epigenetic silencing to maintain leukemic gene expression in MLL-rearranged leukemia. Nat Med. 2015;21(4):335-43.

16. Daigle SR, Olhava EJ, Therkelsen CA, Majer CR, Sneeringer CJ, Song J, et al. Selective killing of mixed lineage leukemia cells by a potent small-molecule DOT1L inhibitor. Cancer Cell. 2011;20(1):53-65.

17. Basavapathruni A, Jin L, Daigle SR, Majer CR, Therkelsen CA, Wigle TJ, et al. Conformational adaptation drives potent, selective and durable inhibition of the human protein methyltransferase DOT1L. Chem Biol Drug Des. 2012;80(6):971-80.

18. Daigle SR, Olhava EJ, Therkelsen CA, Basavapathruni A, Jin L, Boriack-Sjodin PA, et al. Potent inhibition of DOT1L as treatment of MLL-fusion leukemia. Blood. 2013;122(6):1017-25.

19. Yu W, Chory EJ, Wernimont AK, Tempel W, Scopton A, Federation A, et al. Catalytic site remodelling of the DOT1L methyltransferase by selective inhibitors. Nat Commun. 2012;3:1288.

20. Warner JK, Wang JC, Takenaka K, Doulatov S, McKenzie JL, Harrington L, et al. Direct evidence for cooperating genetic events in the leukemic transformation of normal human hematopoietic cells. Leukemia. 2005;19(10):1794-805.

21. Sabatino M, Rotili D, Patsilinakos A, Forgione M, Tomaselli D, Alby F, et al. Disruptor of telomeric silencing 1-like (DOT1L): disclosing a new class of non-nucleoside inhibitors by means of ligand-based and structure-based approaches. J Comput Aided Mol Des. 2018;32(3):435-58.

22. Martinez NJ, Simeonov A. Cell-based assays to support the profiling of small molecules with histone methyltransferase and demethylase modulatory activity. Drug Discov Today Technol. 2015;18:9-17.

23. Li KK, Luo C, Wang D, Jiang H, Zheng YG. Chemical and biochemical approaches in the study of histone methylation and demethylation. Med Res Rev. 2012;32(4):815-67.

24. Sayegh J, Webb K, Cheng D, Bedford MT, Clarke SG. Regulation of protein arginine methyltransferase 8 (PRMT8) activity by its N-terminal domain. J Biol Chem. 2007;282(50):36444-53.

25. H. Zeng WX. Enzymatic Assays of Histone Methyltransferase Enzymes,. Boston: Y.G. Zheng (Ed.), Epigenetic Technol. Appl., Academic Press; 2015.

26. X.-C. Cai KK, M. Luo,. Synthesis and Assays of Inhibitors of Methyltransferases,: Marmorstein (Ed.), Methods Enzymol., Academic Press; 2016. 
27. Chen S, Li L, Chen Y, Hu J, Liu J, Liu YC, et al. Identification of Novel Disruptor of Telomeric Silencing 1-like (DOT1L) Inhibitors through Structure-Based Virtual Screening and Biological Assays. J Chem Inf Model. 2016;56(3):527-34.

28. Song Y, Li L, Chen Y, Liu J, Xiao S, Lian F, et al. Discovery of potent DOT1L inhibitors by AlphaLISA based High Throughput Screening assay. Bioorg Med Chem. 2018;26(8):1751-8.

29. Yu W, Smil D, Li F, Tempel W, Fedorov O, Nguyen KT, et al. Bromo-deaza-SAH: a potent and selective DOT1L inhibitor. Bioorg Med Chem. 2013;21(7):1787-94.

30. Dhayalan A, Dimitrova E, Rathert P, Jeltsch A. A continuous protein methyltransferase (G9a) assay for enzyme activity measurement and inhibitor screening. J Biomol Screen. 2009;14(9):1129-33.

31. Rathert $\mathrm{P}$, Cheng $\mathrm{X}$, Jeltsch A. Continuous enzymatic assay for histone lysine methyltransferases. BioTechniques. 2007;43(5):602, 4, 6 .

32. Wu J, Xie N, Feng Y, Zheng YG. Scintillation proximity assay of arginine methylation. J Biomol Screen. 2012;17(2):237-44.

33. Chen C, Zhu H, Stauffer F, Caravatti G, Vollmer S, Machauer R, et al. Discovery of Novel Dot1L Inhibitors through a Structure-Based Fragmentation Approach. ACS Med Chem Lett. 2016;7(8):735-40.

34. Yi JS, Federation AJ, Qi J, Dhe-Paganon S, Hadler M, Xu X, et al. Structure-guided DOT1L probe optimization by label-free ligand displacement. ACS Chem Biol. 2015;10(3):667-74.

35. Zhu B, Zhang H, Pan S, Wang C, Ge J, Lee JS, et al. In Situ Proteome Profiling and Bioimaging Applications of Small-Molecule Affinity-Based Probes Derived From DOT1L Inhibitors. Chemistry. 2016;22(23):7824-36.

36. Egelhofer TA, Minoda A, Klugman S, Lee K, Kolasinska-Zwierz P, Alekseyenko AA, et al. An assessment of histone-modification antibody quality. Nat Struct Mol Biol. 2011;18(1):91-3.

37. L. Beaudet RR-S, M.-H. Venne, M. Caron, J. Bédard, V. Brechler, S. Parent, M. BielefeldSévigny. AlphaLISA immunoassays: the no-wash alternative to ELISAs for research and drug discovery. Nat Methods. 2008;5:A10-A1.

38. Ullman EF, Kirakossian H, Switchenko AC, Ishkanian J, Ericson M, Wartchow CA, et al. Luminescent oxygen channeling assay (LOCI): sensitive, broadly applicable homogeneous immunoassay method. Clin Chem. 1996;42(9):1518-26.

39. Campbell CT, Haladyna JN, Drubin DA, Thomson TM, Maria MJ, Yamauchi T, et al. Mechanisms of Pinometostat (EPZ-5676) Treatment-Emergent Resistance in MLL-Rearranged Leukemia. Mol Cancer Ther. 2017;16(8):1669-79.

40. Boutros M, Heigwer F, Laufer C. Microscopy-Based High-Content Screening. Cell. 2015;163(6):1314-25.

41. Kim W, Bird GH, Neff T, Guo G, Kerenyi MA, Walensky LD, et al. Targeted disruption of the EZH2-EED complex inhibits EZH2-dependent cancer. Nat Chem Biol. 2013;9(10):643-50.

42. Scheufler C, Mobitz H, Gaul C, Ragot C, Be C, Fernandez C, et al. Optimization of a Fragment-Based Screening Hit toward Potent DOT1L Inhibitors Interacting in an Induced Binding Pocket. ACS Med Chem Lett. 2016;7(8):730-4.

43. Mobitz H, Machauer R, Holzer P, Vaupel A, Stauffer F, Ragot C, et al. Discovery of Potent, Selective, and Structurally Novel Dot1L Inhibitors by a Fragment Linking Approach. ACS Med Chem Lett. 2017;8(3):338-43.

44. Yang L, Lin C, Jin C, Yang JC, Tanasa B, Li W, et al. lncRNA-dependent mechanisms of androgen-receptor-regulated gene activation programs. Nature. 2013;500(7464):598-602.

45. Soria-Valles C, Osorio FG, Gutierrez-Fernandez A, De Los Angeles A, Bueno C, Menendez $\mathrm{P}$, et al. NF-kappaB activation impairs somatic cell reprogramming in ageing. Nat Cell Biol. 2015;17(8):1004-13.

46. Soria-Valles C, Osorio FG, Lopez-Otin C. Reprogramming aging through DOT1L inhibition. Cell Cycle. 2015;14(21):3345-6. 
